\title{
Motility and Flagellation of Cellulomonads
}

\author{
DONALD W. THAYER \\ Eastern Regional Research Center, Agricultural Research Service, U.S. Department of Agriculture, Philadelphia, \\ Pennsylvania 19118
}

\begin{abstract}
The flagellation and motility of seven cellulomonads (Cellulomonas biazotea ATCC $486^{\mathrm{T}}$, [T $=$ type strain], Cellulomonas fimi ATCC $484^{\mathrm{T}}$, Cellulomonas flavigena ATCC $482^{\mathrm{T}}$, Cellulomonas gelida ATCC $488^{\mathrm{T}}$, "Cellulomonas subalbus" ATCC 489, Cellulomonas cellasea ATCC $487^{\mathrm{T}}$, and Cellulomonas uda ATCC $491^{\mathrm{T}}$ ) were examined by light microscopy and electron microscopy. Cells of all seven strains possessed polar multitrichous flagella, and a few cells possessed polar monotrichous flagella.
\end{abstract}

The genus Cellulomonas Bergey et al. (1) was based originally on a single, physiological property, the ability to hydrolyze cellulose. This genus included such varied types of bacteria as nonsporeforming, gram-negative, rod-shaped, polarly flagellated species, peritrichous, gram-variable, rodshaped organisms now placed in the genus Pseudomonas, and the coryneform group of bacteria. Clark (4-7) revised the criteria for species differentiation in Cellulomonas, and this revision was used in Bergey's Manual of Determinative Bacteriology, 7th ed. (3). In Bergey's Manual, 8th ed., Keddie (8) recognized only a single species. However, the reduction of Cellulomonas to a single species has been challenged $(2,10)$.

Previously, motility and type of flagellation were used in differentiating the cellulomonads (6). Kellerman et al. (9) described Cellulomonas biazotea, Cellulomonas cellasea, and Cellulomonas gelida as having one to three peritrichous flagella. Clark and Carr (7) reported one to four flagella for Cellulomonas fimi and C. gelida; these flagella were arranged in polar or lateral positions. Yamada and Komagata (11) reported motility in Cellulomonas species and noted that the flagellation of these organisms was lateral with one, two, or more flagella. Stackebrandt and Kandler (10) observed motility in some of the Cellulomonas strains which they examined but did not determine the type of flagellation. The purpose of this study was to determine the type of flagellation of representative species of the genus Cellulomonas in order to provide accurate morphological descriptions of members of this genus.

The following bacterial species were obtained from the American Type Culture Collection, Rockville, Md.: C. biazotea ATCC $486^{\mathrm{T}},\left(\mathrm{T}=\right.$ type strain), C. cellasea ATCC $487^{\mathrm{T}}$, C. fimi ATCC $484^{\mathrm{T}}$, Cellulomonas flavigena ATCC $482^{\mathrm{T}}, C$, gelida ATCC 488 ${ }^{\mathrm{T}}$, "Cellulomonas subalbus" ATCC 489, and Cellulomonas uda ATCC $491^{\mathrm{T}}$.

Bacteria from 18-, 24-, and 48-h cultures were harvested by centrifugation and suspended in physiological saline for $25 \mathrm{~min}$ at $35^{\circ} \mathrm{C}$ before examination. The cultures were grown in medium adjusted to $\mathrm{pH} 7.0$ and containing $5 \mathrm{~g}$ of tryptone, (Difco Laboratories), $5 \mathrm{~g}$ of yeast extract (BBL Microbiology Systems), $5 \mathrm{~g}$ of $\mathrm{K}_{2} \mathrm{HPO}_{4}, 0.5 \mathrm{~g}$ of glucose, and $1,000 \mathrm{ml}$ of distilled water. The bacteria were negatively stained with a filter-sterilized $2 \%$ phosphotungstic acid solution $(\mathrm{pH} 7.3)$, and they were examined with an Hitachi model HU-8 transmission electron microscope.

Motile cells were observed by phase-contrast microscopic examination of hanging drop suspensions from cultures of all seven strains. The percentage of motile cells varied greatly. The cultures of $C$. biazotea, C. fimi, and C. uda contained relatively few motile cells. Stackebrandt and Kandler (10) reported that cells of " $C$. subalbus" DSM 20110 were motile only when glucose was omitted from the medium and that $C$. biazotea lost its motility when distilled water was used in the medium.

Clearly attached polar multitrichous flagella were demonstrated by electron microscopy of all strains. A few cells had single polar flagella. Representative results for four of the seven strains examined are shown in Fig. 1. No differences in location of attachment or number of flagella among species were found. The number of flagella per cell varied from one to four, with two to four being the most common. The flagella were apparently nonsheathed and had typical basal hooks. However, the resolution of the electron micrographs did not allow the structure of either the hook or the flagellum to be determined.

In this study seven Cellulomonas strains were examined for motility and the point of flagellum attachment by electron microscopy. My evidence indicates that the majority of cells have polar multitrichous flagella and that this should be the correct morphological description for members of this genus. Lateral flagella with clear evidence of attachment were not observed.

A portion of this study was completed at Texas Tech University and was supported by grants from the Dodge Jones Foundation.

I am grateful for the technical assistance of Grace Yong and Dennis Owens and for the critical comments and helpful suggestions of Jerry D. Berlin, Robert Carroll, and Susan Jones.

\section{LITERATURE CITED}

1. Bergey, D. H., R. S. Breed, R. W. Hammer, F.-C. Harrison, and F. M. Huntoon. 1923. Bergey's manual of determinative bacteriology, 1st ed. The Williams \& Wilkins Co., Baltimore, Md.

2. Braden, A. R., and D. W. Thayer. 1976. Seriological study of Cellulomonas. Int. J. Syst. Bacteriol. 26:123-126.

3. Breed, R. S., E. G. D. Murray, and N. R. Smith. 1957. Bergey's manual of determinative bacteriology, 7 th ed. The Williams \& Wilkins Co., Baltimore, Md.

4. Clark, F. E. 1951. The generic classification of certain cellulolytic bacteria. Soil Sci. Soc. Am. Proc. 15:180-182.

5. Clark, F. E. 1952. The generic classification of the soil coryneform bacteria. Int. Bull. Bacteriol. Nomencl. Taxon. 2:45-46.

6. Clark, F. E. 1953. Criteria suitable for species differentiation in Cellulomonas and a revision of the genus. Int. Bull. Bacteriol. Nomencl. Taxon. 3:179-199.

7. Clark, F. E., and P. H. Carr. 1951. Motility and flagellation of the soil corynebacteria. J. Bacteriol. 62:1-6.

8. Keddie, R. M. 1974. Cellulomonas, p. 629-631. In R. E. Buchanan and N. E. Gibbons (ed.), Bergey's manual of determinative bacteriology, 8th ed. The Williams \& Wilkins Co., Baltimore, Md.

9. Kellerman, K. F., I. G. McBeth, F. M. Scales, and N. R. Smith. 

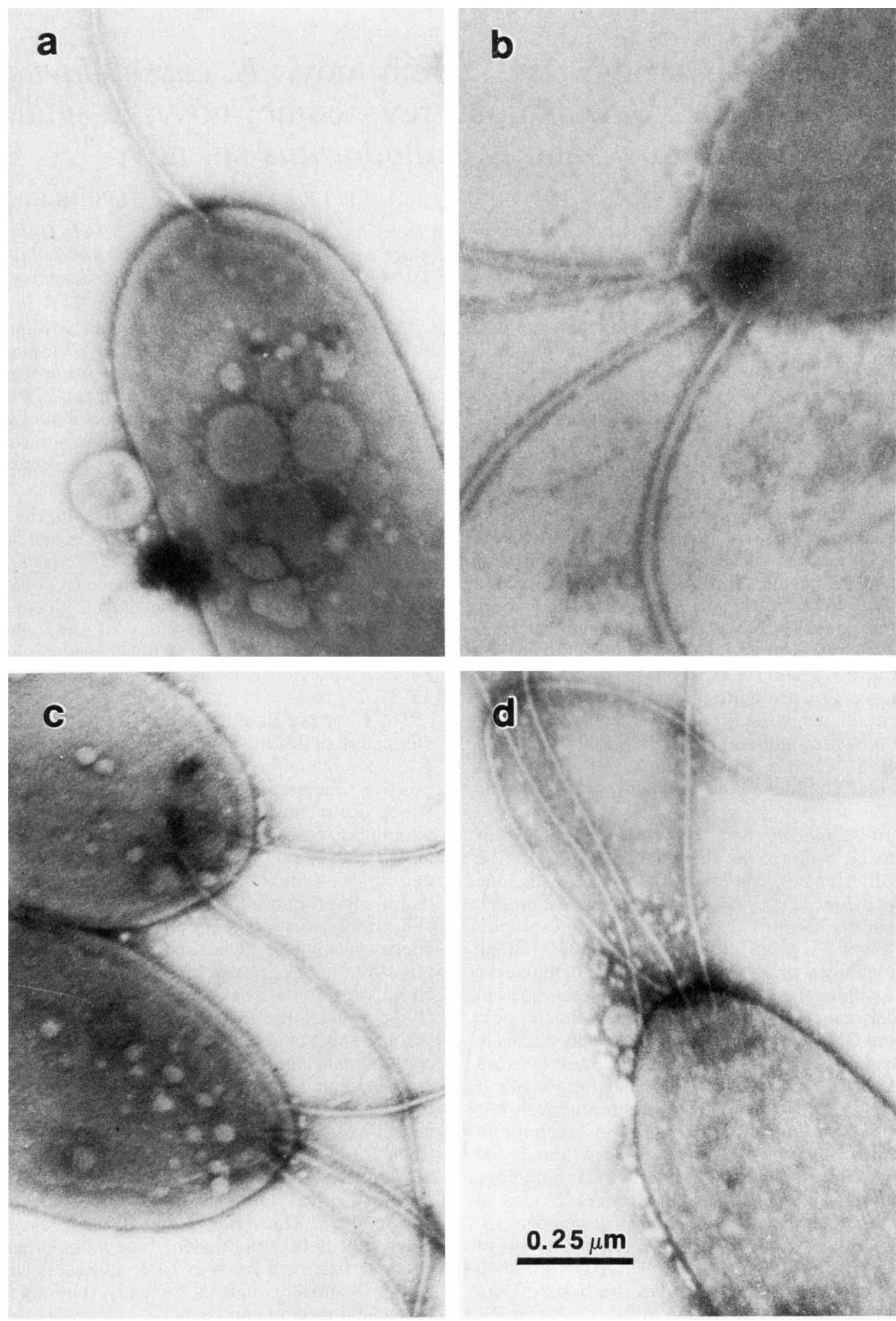

FIG. 1. Electron micrographs of typical negatively stained Cellulomonas cells. Each micrograph is at the same magnification. (a) $C$. cellasea. (b) C. biazotea. (c) C. cellasea. (d) "C. subalbus."

1913. Identification and classification of cellulose-dissolving bacteria. Centralbl. Bakteriol. Abt. 2 39:502-522.

10. Stackebrandt, E., and O. Kandler. 1979. Taxonomy of the genus Cellulomonas, based on phenotypic characters and deoxyribonucleic acid-deoxyribonucleic acid homology, and proposal of seven neotype strains. Int. J. Syst. Bacteriol. 29:273-282.

11. Yamada, K., and K. Komagata. 1972. Taxonomic studies on coryneform bacteria. IV. Morphological, cultural, biochemical, and physiological characteristics. J. Gen. Appl. Microbiol. 18:399-416. 